\title{
Produksi dan Nilai Nutrisi Pada Pertumbuhan Kembali Beberapa Legum Pohon Dengan Umur Pemangkasan Berbeda
}

\section{(Production and Nutrirition Value of Regrowth of Several Tree Legumes with Different Cutting Interval)}

\author{
Yusuf Akhyar Sutaryono, Uhud Abdullah, Imran, Harjono, Mastur dan Ryan Aryadin Putra \\ Fakultas Peternakan Universitas Mataram \\ Jl. Majapahit 62. Mataram 83125 NTB. Telpon (0370) 633603; Fax (0370) 640592 \\ Email: ysf_25@yahoo.com
}

Diterima : 30 Oktober 2019/Disetujui : 26 Nopember 2019

\begin{abstract}
ABSTRAK
Penelitian ini bertujuan untuk mengetahui pertumbuhan, produksi dan nilai nutrisi 5 (lima) legum pohon yang ditanam tanpa pengairan dan dipangkas pada musim kemarau. Legum pohon telah berumur satu tahun pada saat penelitian dimulai. Legume dipotong paksa setinggi $150 \mathrm{~cm}$ dari permukaan tanah untuk penyeragaman. Masing-masing masing legume terdiri atas 15 tanaman dengan jarak tanam $2 \times 1$ meter dan diperlakukan umur pemangkasan tanaman 1, 2 dan 3 bulan setelah potong paksa. Parameter yang diukur adalah pertumbuhan, produksi hijauan dan kualitas nutrisi berupa kandungan bahan kering, protein kasar, serat kasar, KcBK dan KcBO. Data dianalisis dengan analisis of varian berdasarkan rancangan acak kelompok dan perbedaan antar perlakuan dianalisis uji beda Duncan. Hasil penelitian menunjukkan legume pohon yang ditanam pada musim kemarau tetap dapat menghasilkan hijauan pakan yang baik dan disukai oleh ternak ruminansia. Kaliandra menunjukkan pertumbuhan kembali dan hijauan paling tinggi tetapi nilai kecernaan paling rendah. Legume pohon lainnya yang mendekati produksi Kaliandra adalah Turi dan Indigofera. Nilai kandungan protein legume menunjukkan nilai yang lebih rendah dibandingkan dengan kandungan protein legume pohon yang tumbuh pada musim hujan. Semua legume menunjukkan palatabilitas yang baik meskipun palatabilitas rendah ditunjukkan oleh Kelor dan Kaliandra. Nilai KcBK dan KcBO cukup tinggi pada Turi, Indigofera, Kelor dan Lamtoro, tetapi rendah pada Kaliandra. Disimpulkan bahwa semua tanaman legum pohon ini berpotensi dikembangkan sebagai sumber pakan ternak sapi dimusim kemarau.
\end{abstract}

Kata kunci : Legum Pohon, Interval Pemotongan, Pertumbuhan, Produksi, Kualitas Nutrisi, Kecernaan.

\begin{abstract}
Research was conducted to find out the growth, production and nutrition value of 5 (five) tree legumes planted without irrigation and were harvested in dry season. All trees were at one year old when the research started and were forced cut at $150 \mathrm{~cm}$ high above ground level. Each tree legume consists of 15 trees with planting distance of $2 \times 1$ meter and harvested with cutting interval of 1,2 and 3 months after forced cut. The parameters measured were growth, forage produced, and the nutrition quality of forage as in form of dry matter content, crude protein content, crude fiber content, dry matter digestibility and organic matter digestibility. Data were analyzed with analysis of variance based on randomized block design and the differences then analyzed with Duncan new multiple range test. Result showed that tree legumes planted in dry season without irrigation could produce enough amount of forages and palatable to the cattle. Calliandra showed highest regrowth and also produced highest forages but with lowest digestibility. Others tree legumes those produced similar production to Calliandra were Sesbania and Indigofera. The crude protein content in tree legumes grow in dry season without irrigation was lower compared to those grow in rainy season. All legumes showed good palatability although lower palatability was showed by Moringa and Calliandra. The value of dry matter and organic matter digestibility were high for Sesbania, Indigofera, Moringa and Leucaena, but low for Calliandra. It is concluded that all tree legumes planted were potential to be developed as feed resources for cattle in the dry season.
\end{abstract}

Keywords: Tree Legumes, Cutting Interval, Growth, Production, Nutrition Quality, Digestibility 


\section{PENDAHULUAN}

Kekurangan pakan dimusim kemarau adalah kendala utama dalam pemeliharaan ternak ruminansia extensif di wilayah Indonesia bagian timur. Hal ini disebabkan terbatasnya ketersediaan hijauan pakan sepanjang tahun dan rendahnya kualitas nutrisi hijauan pakan terutama dimusim kemarau (Bamualim 2009). Rendahnya produktifitas dan kualitas nutrisi hijaun pakan semakin diperparah dengan semakin menyempitnya areal penggembalaan ternak dan tidak adanya lahan yang dapat dikembangkan khusus untuk menanam tanaman pakan. Untuk mengatasi keterbatasan pakan terutama musim kemarau diperlukan altenatif lainnya untuk menyediakan hijauan pakan ternak selain rumput salah satunya yaitu legum pohon.

Tanaman legum pohon secara masif telah dikembangkan sebagai sumber pakan terutama bagi ternak ruminansia, diantaranya yaitu lamtoro, turi, kaliandra, indigofera dan kelor. Legum pohon tersebut sangat potensial untuk dikembangkan sebagai sumber pakan hijauan guna mengatasi kekurangan pakan dimusim kemarau. Hijauan pakan yang diperoleh dari legum pohon ini sangat disukai oleh ternak ruminansia dan memiliki kandungan protein yang sangat tinggi. Hampir semua jenis legum pohon tersebut dapat tumbuh dengan baik dan sudah dikembangkan sebagai pakan ternak di Nusa Tenggara Barat.

Tanaman legum akan tumbuh dan berproduksi kembali jika direnggut/dipangkas dan dimanfaatkan selama fase vegetatif (Purbajanti, 2013). Namun setiap spesies tanaman legum dan/atau pakan memberikan respon yang berbeda terhadap cekaman yang diperolehnya. Pada spesies legum tertentu seperti alfalfa menunjukkan kemampuan masih dapat tumbuh dengan baik setelah injak dan direnggut oleh ternak akan tetapi ada juga spesies yang tidak mampu tumbuh lagi pasca gembala (Barnes et al., 2007).
Bagi tanaman pakan, organ-organ yang mengalami pertumbuhan adalah akar, daun dan batang. Pertumbuhan yang cepat dan lebat mempengaruhi kadar bahan kering hijauan. Koten et al. (2012) melaporkan bahwa umur 100 hari merupakan umur panen yang terbaik sebagai pakan ternak yang dimanfaatkan dengan cara dipotong.

Pertumbuhan tanaman secara akumulasi dipengaruhi oleh tingkat laju fotosintesis tanaman yang ditunjukkan dengan meningkatnya jumlah daun dan indeks luas daun (Sumiahadi et al., 2016). Pertumbuhan dan perkembangan tanaman akan berlangsung seumur hidup tergantung pada tersedianya meristem, hasil asimilasi, hormon dan substansi pertumbuhan lainnya, serta lingkungan yang mendukung (Gardner et al., 2008). Koten et al. (2017) menyatakan bahwa pertumbuhan dan perkembangan tanaman merupakan proses yang penting dalam kehidupan dan perkembangbiakan suatu spesies. Semakin banyak biomassa daun dan tunas percabangan yang tumbuh kembali pasca pemotongan tentu berpengaruh terhadap produksi tanaman tersebut sebagai pakan. Dengan demikian, menjadi penting dan perlu untuk dilakukan suatu kajian yang komrehensif beberapa spesies tanaman legum pohon dengan umur pemangkasan berbeda terhadap produksi dan nilai nutrisinya.

\section{MATERI DAN METODE}

Sejumlah 5 spesies legum pohon yaitu Lamtoro, Turi, Indigofera, Kaliandra dan Kelor yang telah berumur 1 tahun telah digunakan dalam penelitian ini. Pada awal penelitian semua tanaman diseragamkan dengan dilakukan pemotongan paksa dengan ketinggian $150 \mathrm{~cm}$ diatas tanah. Periode pemangkasan (panen) untuk tiap kelompok tanaman adalah 1 bulan (30 hari), 2 bulan ( 60 hari) dan 3 bulan ( 90 hari). Data pertumbuhan tanaman dikoleksi dengan mengukur tinggi tanaman dan jumlah percabangan dan data produksi hijauan diperoleh pada setiap periode 
pemangkasan. Data kualitas nutrisi legum diperoleh dengan melakukan pengujian terhadap kandungan bahan kering (BK) dan protein kasar (PK) serta nilai kecernaan secara in vitro (KcIV). Analisis nilai bahan kering (BK) dan protein kasar (PK) dan serat kasar (SK) mengikuti prosedur AOAC (2005) dan nilai kecernaan in vitro bahan kering (KcBK) dan bahan organik (KcBO) menggunakan metode Tilley and Terry (1963). Selanjutnya data yang diperoleh selama penelitian dianalisis menggunakan analisis varian berdasarkan rancangan acak kelompok dan dilanjutkan dengan uji beda nyata Duncan (Steel and Torrie, 1991) .

\section{HASIL DAN PEMBAHASAN}

\section{Tinggi tanaman}

Pertumbuhan dan perkembangan tanaman merupakan proses yang penting dalam kehidupan dan perkembangbiakan suatu spesies (Koten et al., 2017). Hasil penelitian menunjukkan semua jenis legume pohon yang diteliti tumbuh kembali dengan baik setelah mendapatkan perlakuan potong paksa setinggi $150 \mathrm{~cm}$ dari permukaan tanah. Tanaman menghasilkan tunas dan tumbuh berkembang dan menghasilkan hijuan pakan. Pertumbuhan tanaman cukup bagus dan memperlihatkan pertumbuhan yang normal meskipun dengan musim kemarau yang panas dan kering.

Tercatat bahwa pertumbuhan tercepat ditunjukkan oleh tanaman kelor, bertumbuh rata-rata $71 \mathrm{~cm}$ dalam satu bulan pertama, kemudian diikuti oleh kaliandra $(68 \mathrm{~cm})$, Turi $(53 \mathrm{~cm})$ dan Indigofera $(40 \mathrm{~cm})$. Lamtoro menunjukkan pertumbuhan yang paling rendah dengan pertambahan tinggi tanaman rata-rata hanya $24 \mathrm{~cm}$ dalam satu bulan pertama. Pada waktu 2 bulan setelah pemotongan kelor tumbuh paling cepat dengan bertambah sebesar $\pm 100 \mathrm{~cm}$, disusul oleh pertumbuhan turi dan kaliandra yang bertambah sekitar $90 \mathrm{~cm}$. Sementara Lamtoro dan Indigofera bertumbuh paling rendah dengan pertambahan tinggi sekitar $70 \mathrm{~cm}$.

Umur 3 bulan setelah pemotongan, kelor tetap menunjukkan pertumbuhan yang paling cepat dengan pertambahan tinggi tanaman sebesar $170 \mathrm{~cm}$, kemudian diikuti oleh tanaman Turi yang bertambah tinggi sebesar $103 \mathrm{~cm}$, kemudian tanaman Kaliandra bertambah tinggi sebesar $100 \mathrm{~cm}$ dan pertumbuhan terendah adalah pada tanaman Indigofera yang bertambah tinggi sebesar $95 \mathrm{~cm}$. Perbedaan kecepatan pertumbuhan setelah pemotongan diduga disebabkan oleh perbedaan respon fisiologis tanaman legum tersebut terhadap pemotongan. Salysbury (1995) menyatakan bahwa salah satu yang dapat mempengaruhi pertumbuhan tanaman adalah laju fotosintesa pada bagian tanaman yang mengandung chlorofil, sedang fotosintesa sangat tergantung pada intensitas dan radiasi sinar matahari. Penyimpanan karbohidrat terlarut dari tanaman umumnya terdapat pada bagian daun, batang, dan akar sebagai kontribusi atas aktivitas fotosintesis.

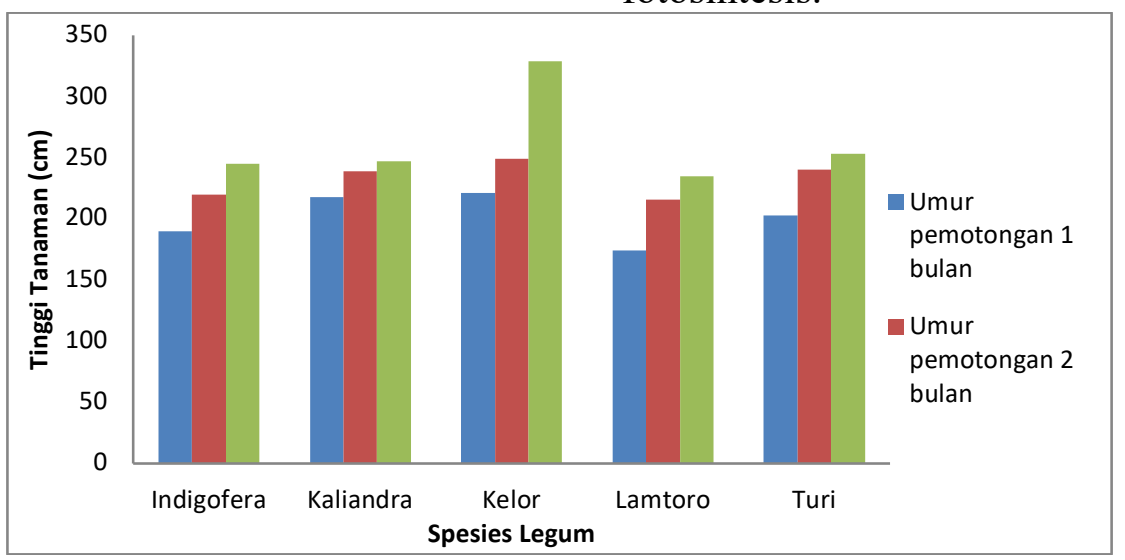

Gambar 1. Tinggi tanaman dari beberapa spesies legum yang ditanam pada musim kemarau 
Data pada Tabel 1 menunjukkan tinggi pertumbuhan pada bulan pertama tertinggi diperoleh pada kelor dan kaliandra serta terlihat tidak berbeda nyata namun menunjukkan perbedaan tinggi yang nyata dengan 3 spesies legume pohon yang lain $(\mathrm{P}<0,05)$. Pada bulan kedua, pertambahan tinggi tanaman tertinggi juga terjadi pada tanaman Kelor dan Kaliandra, akan tetapi pada bulan kedua tinggi tanaman Turi tidak berbeda nyata mendekati tinggi tanaman Kelor dan Kaliandra.

Selanjutnya pada bulan ketiga kaliandra tetap menunjukkan pertambahan tinggi tanaman yang tertinggi $(329,00 \mathrm{~cm})$ berbeda nyata dengan tanaman yang lain $(\mathrm{P}<0,05)$. Adanya perbedaan respon tinggi tanaman setelah dipotong kemungkinan besar disebabkan oleh perbedaan kemampuan tanaman legum dalam proses fiksasi nitrogen. Peoples dan Craswell (1992) menyatakan bahwa tiap jenis legum mempunyai kemampuan yang berbeda dalam memfiksasi nitrogen. Semakin tinggi aktivitas nitrogenase, semakin banyak jumlah nitrogen yang dapat difiksasi sehingga semakin tinggi tingkat pertumbuhannya.

Tabel 1. Tinggi tanaman 5 legume pohon yang ditanam dimusim kemarau

\begin{tabular}{|c|c|c|c|}
\hline \multirow{2}{*}{ Spesies } & \multicolumn{3}{|c|}{ Tinggi tanaman (cm) pada umur potong } \\
\hline & 1 bulan & 2 bulan & 3 bulan \\
\hline Indigofera & $190,00 \pm 11,14 \mathrm{a}$ & $220,00 \pm 11,14 a$ & $245,00 \pm 8,19 \mathrm{a}$ \\
\hline Kaliandra & $218,00 \pm 8,72 \mathrm{ab}$ & $239,00 \pm 8,72 \mathrm{ab}$ & $247,00 \pm 5,00 \mathrm{a}$ \\
\hline Kelor & $221,00 \pm 5,57 b$ & $249,00 \pm 5,57 b$ & $329,00 \pm 15,10 b$ \\
\hline Lamtoro & $174,00 \pm 8,54 a$ & $216,00 \pm 8,54 \mathrm{a}$ & $235,00 \pm 11,79 a$ \\
\hline Turi & $203,00 \pm 9,00 \mathrm{ab}$ & $240,00 \pm 9,00 \mathrm{ab}$ & $253,00 \pm 9,00 \mathrm{a}$ \\
\hline
\end{tabular}

\section{Produksi hijauan segar.}

Tabel 2 menunjukkan pada 1 bulan setelah pemotongan poduksi hijauan tertinggi diperoleh dari tanaman Kaliandra (2385,00 gram/pohon) yang kemudian diikuti oleh Turi (1759,67 gram/pohon) dan yang terendah adalah produksi tanaman Lamtoro $(1275,00$ gram/pohon $)(\mathrm{P}<0,05)$. Pada masa 2 bulan sesudah pemotongan Kaliandra tetap menghasilkan produksi hijauan yang terting dengan produksi hijuan sebesar 2957,67 gram/pohon diikuti oleh Indigofera dengan hijauan sebesar 2070,00 gram/pohon dan Lamtoro tetap berproduksi paling rendah dengan produksi hijauan sebesar 1775,00 gram/pohon $(\mathrm{P}<0,05$; Tabel 2). Tingginya produksi hijauan segar indigofera diduga disebabkan karena tanaman ini mempunyai sel yang cukup aktif untuk melakukan proses pembelahan sel maupun pembentukan jaringan setelah dilakukan pemotongan.
Pertumbuhan kembali Kaliandra pada 3 kali periode pemotongan selama 3 bulan tetap menunjukkan produksi hijauan yang tertinggi (4953,33 gram/pohon) yang disusul oleh turi (3905,00 gram/pohon) dan Indigofera (3896,67 gram/pohon) sementara produksi kelor dan Lamtoro tetap terendah dalam periode pemotongan tersebut dengan masing-masing sebesar 2313,67 gram/pohon dan 2398,33 gram/pohon. Produksi hijauan segar kaliandra dengan produksi yang tertinggi berbeda nyata dengan produksi hijauan segar 4 jenis legum pohon yang lain yang lebih rendah. Sementara produksi segar indigofera dan turi sebagai produksi hijauan kedua dan ketiga tertinggi tidak berbeda nyata diantara keduanya. Mansyur et al. (2005) menyatakan adanya kecenderungan perubahan produksi segar dengan lama umur pemotongan dikarenakan proporsi bahan kering yang dikandung oleh suatu tanaman berubah seiring dengan umur tanaman. 
Tabel 2. Produksi hijauan segar legume pohon yang dipanen dimusim kemarau

\begin{tabular}{llll}
\hline \multirow{2}{*}{ Spesies legum } & \multicolumn{3}{c}{ Produksi hijauan (segar, gram/pohon) pada umur potong } \\
\cline { 2 - 4 } & \multicolumn{1}{c}{$\mathbf{1}$ bulan } & \multicolumn{1}{c}{$\mathbf{2}$ bulan } & \multicolumn{3}{c}{ 3 bulan } \\
\hline Indigofera & $1655,00 \pm 273,72 \mathrm{ab}$ & $2070,00 \pm 409,27 \mathrm{a}$ & $3896,67 \pm 863,66 \mathrm{~b}$ \\
Kaliandra & $2385,00 \pm 232,86 \mathrm{c}$ & $2957,67 \pm 89,25 \mathrm{~b}$ & $4953,33 \pm 667,66 \mathrm{~b}$ \\
Kelor & $1295,33 \pm 262,18 \mathrm{a}$ & $1966,67 \pm 139,89 \mathrm{a}$ & $2313,67 \pm 463,95 \mathrm{a}$ \\
Lamtoro & $1275,00 \pm 111,69 \mathrm{a}$ & $1775,00 \pm 484,74 \mathrm{a}$ & $2398,33 \pm 215,02 \mathrm{a}$ \\
Turi & $1759,67 \pm 157,18 \mathrm{~b}$ & $2215,00 \pm 43,59 \mathrm{a}$ & $3905,00 \pm 1078,85 \mathrm{~b}$ \\
\hline
\end{tabular}

${ }^{\mathrm{ab}}$ huruf yang berbeda pada kolom yang sama menunjukkan perbedaan nyata $(\mathrm{P}<0.05)$

\section{Kandungan Bahan Kering}

Kandungan bahan kering hijauan legum pohon pada umur pemotongan 1 bulan menunjukkan bahwa Kaliandra memiliki kandungan bahan kering tertinggi $(31,43 \%)$ disusul oleh Indigofera $(30,33 \%)$ kemudian lamtoro, kelor dan turi dengan kandungan bahan kering sebesar 28\%. Meskipun kandugan bahan kering secara numerik terlihat berbeda, kandungan bahan kering pada 1 bulan sesudah potong paksa pada semua legum pohon adalah tidak berbeda nyata.

Tidak terdapat perbedaan yang nyata produksi bahan kering pada umur pemotongan 2 bulan. Kandungan bahan kering hijauan legum rata-rata meningkat seiring dengan makin tingginya aktifitas forosintesis. Pada umur pemotongan 2 bulan, kaliandra tetap memiliki kandungan bahan kering tertinggi $(32,51 \%)$ diikuti oleh kelor $(31,36 \%)$ dan indigofera (30,84\%). Kandungan bahan kering terendah dimiliki oleh turi dengan kandungan bahan kering sebesar 24,76\%. Semakin meningkatnya kandungan bahan kering hijauan legum tesebut selaras dengan pertambahan umur tanaman itu sendiri. Djuned et al. (2005) menyatakan bahwa tanaman yang usia tua terjadi penebalan dinding sel yang mengakibatkan kandungan bahan kering meningkat. Semakin tinggi umur tanaman maka komponen dinding sel suatu hijauan akan semakin tinggi. Semakin tua tanaman maka akan lebih sedikit kandungan airnya dan proporsi dinding selnya lebih tinggi dibandingkan dengan isi sel. Kandungan dinding sel yang semakin tinggi, maka tanaman tersebut akan lebih banyak mengandung bahan kering.

Seperti halnya pada umur pemotongan 2 bulan, umur pemotongan 3 bulan juga menunjukkan kandungan bahan kering semua hijauan legume pohon meningkat dengan kandungan bahan kering tertinggi diperoleh pada kaliandra $(34,13 \%)$ disusul oleh Indigofera $(30,81 \%)$ kemudian lamtoro (29,31\%) dan turi (29,09\%). Kandungan bahan kering terendah pada umur pemotongan 3 bulan adalah kelor dengan bahan kering sebesar 28,48\%. Salisbury dan Ross, (1995) menyatakan bahwa semakin tinggi tingkat pertumbuhan, semakin tinggi pula produksi bahan keringnya. Namun demikian, berdasarkan Uji beda nyata pada umur potong 3 bulan memperlihatkan bahwa kandungan bahan kering pada kaliandra, indigofera tidak berbeda nyata, keduanya hanya menunjukkan perbedaan yang nyata dengan turi, lamtoro dan kelor $(\mathrm{P}<0,05)$. Reksohadiprodjo (1994), faktor-faktor yang mempengaruhi kadar bahan kering diantara; jenis tanaman, fase pertumbuhan, saat pemotongan, air tanah serta kesuburan tanah. Kandungan bahan kering tanaman pada musim penghujan relative rendah karena pertumbuhan tanaman lebih cepat, air tercukupi dan kondisi lingkungan lembab sehingga transpirasi berkurang 
Tabel 3. Kandungan Bahan Kering (\%) berbagai legume yang dipanen dimusim kemarau

\begin{tabular}{lccc}
\hline \multirow{2}{*}{ Spesies legume } & \multicolumn{3}{c}{ Bahan Kering (\%) pada umur potong } \\
\cline { 2 - 4 } & 1 bulan & 2 bulan & 3 bulan \\
\hline Indigofera & $30.33 \pm 2.11 \mathrm{a}$ & $30.84 \pm 2.40 \mathrm{a}$ & $30.81 \pm 2.25 \mathrm{ab}$ \\
Kaliandra & $31.43 \pm 2.15 \mathrm{a}$ & $32.51 \pm 2.20 \mathrm{a}$ & $34.13 \pm 2.56 \mathrm{a}$ \\
Kelor & $28.67 \pm 2.22 \mathrm{a}$ & $31.36 \pm 2.60 \mathrm{a}$ & $28.48 \pm 2.35 \mathrm{~b}$ \\
Lamtoro & $28.72 \pm 2.13 \mathrm{a}$ & $31.15 \pm 2.50 \mathrm{a}$ & $29.31 \pm 2.24 \mathrm{~b}$ \\
Turi & $28.03 \pm 2.21 \mathrm{a}$ & $24.76 \pm 2.10 \mathrm{~b}$ & $29.09 \pm 2.16 \mathrm{~b}$ \\
\hline
\end{tabular}

Keterangan: huruf yang sama pada kolom yang sama menunjukkan tidak berbeda nyata $(p=0.05)$

\section{Kandungan Bahan Organik}

Tabel 4 menunjukkan seluruh 5 spesies hijauan legume pohon memiliki kandungan bahan organik diatas $90 \%$. Pada umur pemotongan 1 bulan kaliandra memiliki kandungan bahan organik tertinggi sebesar $94,31 \%$ disusul oleh kelor $(92,26 \%)$ dan kemudian lamtoro, Turi dan Indigofera masing-masing $91,81 \%, 91,81 \%$ dan 91,64\%. Kandungan bahan organik pada pemotongan 1 bulan menunjukkan linear dengan kandungan bahan keringnya. Hal ini sesuai dengan pernyataan Tillman et al. (1998) yang menyatakan bahwa kandungan porsi bahan kering suatau tanaman akan sejalan dengan porsi kandungan bahan organiknya.
Umur pemotongan 2 bulan menunjukkan kandungan bahan organik tertinggi ditunjukkan oleh indigofera, kaliandra dan turi masing-masing sebesar 93,93\%, 93,92\% dan 93,28\%. Pada umur pemotongan ini kandungan bahan organik terendah adalah hijauan legum kelor sebesar $90,50 \%$. Pada umur pemotongan 3 bulan, kaliandra tetap memiliki kandungan bahan organik tertinggi $(94,20 \%)$ disusul oleh lamtoro $(93,33 \%)$, turi $(93,02 \%)$ dan paling rendah adalah indigofera sebesar 92,07\%. Seluruh nilai kandungan bahan organik pada legum pohon ini tidak berbeda nyata.

Tabel 4. Kandungan Bahan Organik (\%) berbagai legume

\begin{tabular}{lccc}
\hline \multirow{2}{*}{ Spesies legume $^{\text {ns }}$} & \multicolumn{2}{c}{ Bahan Organik (\%) pada umur potong ${ }^{\text {ns }}$} \\
\cline { 2 - 4 } & \multicolumn{1}{c}{$\mathbf{1}$ bulan } & 2 bulan & 3 bulan \\
\hline Indigofera & $91.64 \pm 2.15$ & $93.93 \pm 2.23$ & $92.07 \pm 2.16$ \\
Kaliandra & $94.31 \pm 2.16$ & $93.92 \pm 2.32$ & $94.20 \pm 2.23$ \\
Kelor & $92.26 \pm 2.17$ & $90.50 \pm 2.26$ & $92.84 \pm 2.41$ \\
Lamtoro & $91.81 \pm 2.12$ & $92.69 \pm 2.21$ & $93.33 \pm 2.11$ \\
Turi & $91.81 \pm 2.11$ & $93.28 \pm 2.31$ & $93.02 \pm 2.19$ \\
\hline ns menunjukkan tidak berbeda nyata & &
\end{tabular}

\section{Kandungan Protein Kasar}

Kandungan protein kasar tanaman legum pohon yang dipanen pada puncak musim kemarau menunjukkan kandungan protein kasar yang relatif rendah dengan kisaran kandungan protein kasar sebesar 15 sampai $17 \%$. Nilai ini jauh lebih rendah dibandingkan dengan kandungan protein kasar tanaman legum pohon pada kondisi normal yang berkisar skitar 21-23\%
(Mannetje dan Jones, 2000). Pada umur pemotongan 1 bulan kandungan protein kasar tertinggi diperoleh pada tanaman Lamtoro $(17,91 \%)$ kemudian disusul oleh Kelor $(16,38 \%)$ dan Turi $(16,25 \%)$ dan terendah pada Indigofera dan Kalindra masing-masing sebesar $15,98 \%$ dan $15,56 \%$.. Pada umur 1 bulan setelah potong paksa, kandungan protein kasar pada turi, lamtoro, kelor dan indigofera tidak berbeda 
nyata, hanya berbeda nyata dengan protein kasar kaliandra.

Pada umur pemotongan 2 bulan lamtoro, turi dan kelor memiliki kandungan protein kasar tertinggi masing-masing sebesar $17,27 \%$ dan $16,15 \%$. Kandungan protein kasar terendah dimiliki oleh Kaliandra dan Indigofera masing-masing sebesar $15,20 \%$ dan $15,36 \%$. Pada umur 2 bulan setelah potong paksa, kandungan protein kasar pada Turi, Lamtoro, Kelor dan Indigofera juga tidak berbeda nyata, hanya berbeda nyata dengan protein kasar Kaliandra.

Terjadi penurunan kandungan protein kasar pada umur pemotongan 3 bulan, meskipun lamtoro, turi dan kelor tetap memiliki kandungan protein kasar tertinggi masing-masing sebesar 16,93\%, $16,90 \%$ dan $16,07 \%$. Sedangkan kandungan protein kasar terendah adalah hijauan legum kaliandra sebesar $15,18 \%$. Pada umur 3 bulan ini meskipun kandungan protein kasar berbeda-beda tetapi setelah diuji beda nyata dengan uji Duncan, ternyata tidak berbeda nyata. Turunnya kandungan protein kasar pada semua legum yang diteliti disebabkan oleh meningkatnya umur pemotongan. Semakin meningkat umur pemotongan maka terjadi perubahan gradien antara porsi protein kasar dengan porsi serat kasar. Sesuai dengan pernyataan Setiyaningrum et al. (2017) yang menyatakan bahwa semakin tua tanaman maka akan lebih sedikit kandungan airnya dan proporsi dinding selnya lebih tinggi dibandingkan dengan isi sel.

Tabel 5. Kandungan Protein Kasar (\%) berbagai legum

\begin{tabular}{llll}
\hline \multirow{2}{*}{ Spesies legume } & \multicolumn{3}{c}{ Protein Kasar (\%) pada umur potong } \\
\cline { 2 - 4 } & \multicolumn{1}{c}{$\mathbf{1}$ bulan } & \multicolumn{1}{c}{$\mathbf{2}$ bulan } & $\mathbf{3}$ bulan \\
\hline Indigofera & $15.98 \pm 1,30 \mathrm{ab}$ & $15.36 \pm 1.60 \mathrm{ab}$ & $15.32 \pm 1.35 \mathrm{a}$ \\
Kaliandra & $15.56 \pm 1.70 \mathrm{a}$ & $15.20 \pm 0.90 \mathrm{a}$ & $15.18 \pm 1.38 \mathrm{a}$ \\
Kelor & $16.38 \pm 1.50 \mathrm{ab}$ & $16.02 \pm 1.80 \mathrm{ab}$ & $15.90 \pm 1.27 \mathrm{a}$ \\
Lamtoro & $17.91 \pm 1.10 \mathrm{~b}$ & $17.27 \pm 1.40 \mathrm{~b}$ & $16.93 \pm 1.42 \mathrm{a}$ \\
Turi & $16.25 \pm 1.20 \mathrm{ab}$ & $16.15 \pm 0.80 \mathrm{ab}$ & $16.07 \pm 1.26 \mathrm{a}$ \\
\hline ab & \multicolumn{3}{c}{ huruf yang berbeda pada kolom yang sama menunjukkan perberbedaan nyata $(\mathrm{P}<0,05)$}
\end{tabular}

\section{Kandungan Serat Kasar}

Kandungan serat kasar hijauan legume pohon rata-rata menunjukkan kandungan serat kasar yang relative rendah dengan kisaran 18 - 28\%. Pada umur pemotongan 1 bulan kandungan serat kasar tertinggi ditunjukkan oleh indigofera sebesar $27,76 \%$ yang disusul oleh lamtoro sebesar $27,10 \%$ dan yang terendah dipeoleh pada tanaman kelor dengan kandungan serat kasar sebesar 18,57\%. Hal serupa terjadi pada umur pemotongan 2 bulan kandungan serat kasar tertinggi dimiliki oleh Indigifera kemudian disusul oleh lamtoro dan yang terendah dimiliki oleh kelor dengan kandungan serat kasar berturut - turut sebesar 28,21\%, 27,18\%, dan $18,76 \%$. Hal ini merupakan repsentasi bahwa kedua legum (indigofera dan lamtoro) tersebut memiliki nilai degradasi pakan yang baik dibandingkan dengan jenis legum lainnya yang digunakan dalam penelitian ini.

Demikian halnya juga pada umur pemotongan 3 bulan indigofera tetap menunjukkan kandungan serat kasat tertinggi sebesar $28,30 \%$ disusul oleh lamtoro $(27,25 \%)$ dan yang terendah adalah kelor $(18,92 \%)$. Tidak berbedanya kandungan serat kasar dengan semakin bertambahnya durasi wajtu pemotongan disebabkan oleh sifat kandungan serat tanaman yang meningkat selaras dengan bertambahnya umur tanaman. Hal ini sesuai dengan pendapat Reksohadiprodjo (1994) yang menyatakan bahwa semakin lama umur pemotongan, maka produksi bahan kering semakin tinggi dan dan diikuti oleh kandungan serat kasar yang meningkat. 
Pertambahan umur tanaman juga menyebabkan kandungan nutrisi menurun, terutama pada daun. Penurunan rasio daun dan batang dapat digambarkan sebagai indicator menurunnya nilai nutrisi dan produksi (Hutabarat et al., 2017).

Tabel 6. Kandungan SK (\%) berbagai legume yang ditanam dimusim kemarau

\begin{tabular}{|c|c|c|c|}
\hline \multirow{2}{*}{ Spesies legume } & \multicolumn{3}{|c|}{ Serat Kasar (\%) pada umur potong } \\
\hline & 1 bulan & 2 bulan & 3 bulan \\
\hline Indigofera & $27.76 \pm 0.23 \mathrm{a}$ & $28.21 \pm 0.17 \mathrm{a}$ & $28.30 \pm 0.23 a$ \\
\hline Kaliandra & $21.33 \pm 0.15 b$ & $21.77 \pm 0.28 b$ & $21.80 \pm 0.24 b$ \\
\hline Kelor & $18.57 \pm 0.23 \mathrm{c}$ & $18.76 \pm 0.18 \mathrm{c}$ & $18.92 \pm 0.24 \mathrm{c}$ \\
\hline Lamtoro & $27.10 \pm 0.22 \mathrm{~d}$ & $27.18 \pm 0.16 \mathrm{~d}$ & $27.25 \pm 0.22 \mathrm{~d}$ \\
\hline Turi & $21.97 \pm 0.14 \mathrm{e}$ & $22.16 \pm 0.21 \mathrm{e}$ & $22.36 \pm 0.23 \mathrm{e}$ \\
\hline
\end{tabular}

\section{Konsumsi hijauan}

Tingkat konsumsi dapat mengambarkan palatabiltas. Ketika hijauan pakan diberikan diberikan dalam keadaan segar kepada ternak sapi, pada umur pemotongan 1 bulan indigofera menunjukkan sebagai hijauan pakan yang paling disukai oleh ternak sapi dengan konsumsi sebesar $66,64 \%$ dan disusul oleh lamtoro $(65,39 \%)$ dan turi $(64,53 \%)$ yang paling sedikit dikonsumsi adalah hijauan kelor (46,90\%). Konsumsi Indigofera ini berbeda nyata dengan konsumsi lamtoro, turi, kaliandra dan kelor. Pada umur pemotongan 2 bulan konsumsi tertinggi ternak sapi adalah hijauan turi $(72,22 \%)$ disusul oleh indigofera $(68,26 \%)$ kemudian lamtoro $(66,49 \%)$ dan yang paling rendah dikonsumsi adalah hijauan kelor $(45,42 \%)$. Konsumsi turi ini berbeda nyata dengan konsumsi lamtoro, kaliandra dan kelor, tetapi tidak berbeda nyata dengan konsumsi Indigofera.

Umur pemotongan 3 bulan hijauan pakan yang paling disukai ternyata adalah lamtoro $(75,11 \%)$ disusul oleh indigofera $(68,26 \%)$ dan turi $(65,73 \%)$. Hijuan yang paling rendah konsumsi pada umur pemotongan 3 bulan adalah kelor. Konsumsi lamtoro berbeda nyata dengan konsumsi kelor dan kaliandra tapi tidak berbeda nyata dengan konsumsi indigofera dan turi. Dari data dapat dilihat bahwa hijauan turi, lamtoro dan indigofera adalah merupakan 3 jenis hijauan legum pohon yang paling disukai oleh ternak sapi, sementara kaliandra dan kelor adalah yang kurang disukai oleh ternak sapi. Hal yang menarik untuk dijadikan bahan kajian selanjutnya adalah pada umur tanaman yang lebih tua yaitu pada umur pemotongan 3 bulan maka lamtoro menunjukkan sebagai jenis hijauan legum pohon yang paling disukai ternak sapi dan disusul oleh Indigofera. Ambisi et.al. (2014) menyatakan bahwa ketersediaan protein yang tinggi dari Indigofera falcata mengakibatkan pertumbuhan mikroba dalam rumen akan tumbuh optimal karena hasil degradasi protein pakan oleh mikroba rumen selain menghasilkan konsentrasi $\mathrm{NH}^{3}$ yang tinggi juga akan menjadi sumber makanan bagi mikroba dalam rumen.

Rendahnya nilai konsumsi kaliandra dan kelor mungkin disebabkan karena kandungan zat anti nutrisi tannin yang tinggi pada kedua jenis legum ini. Menurut Mannetje dan Jones (2000) kandungan tannin pada kaliandra bias mecapai $11 \%$ dari bahan kering sehingga mempengaruhi palatabilitas dari tanaman ini saat dikonsumsi oleh ternak ruminansia. Kandungan tanin suatu legum akan meningkat seiring dengan umur tanaman itu sendiri. 
Tabel 7. Konsumsi ternak sapi (\%) pada berbagai legume yang diberikan di kandang Spesies legume Konsumsi (\%) pada umur potong

\begin{tabular}{lcll}
\cline { 2 - 4 } & \multicolumn{1}{c}{ 1 bulan } & \multicolumn{1}{c}{ 2 bulan } & \multicolumn{1}{c}{ 3 bulan } \\
\hline Indigofera & $66,64 \pm 4,86 \mathrm{a}$ & $68,26 \pm 3,02 \mathrm{ac}$ & $68,26 \pm 4,83 \mathrm{c}$ \\
Kaliandra & $58,95 \pm 0,65 \mathrm{~b}$ & $61,09 \pm 0,58 \mathrm{~b}$ & $52,61 \pm 2,43 \mathrm{a}$ \\
Kelor & $46,90 \pm 1,81 \mathrm{c}$ & $45,42 \pm 5,58$ & $56,39 \pm 9,95 \mathrm{ab}$ \\
Lamtoro & $65,39 \pm 0,50 \mathrm{c}$ & $66,49 \pm 2,68 \mathrm{bc}$ & $75,11 \pm 2,11 \mathrm{c}$ \\
Turi & $64,53 \pm 1,11 \mathrm{c}$ & $72,22 \pm 4,23 \mathrm{c}$ & $65,73 \pm 0,62 \mathrm{bc}$ \\
\hline abc & \multicolumn{2}{c}{ huruf yang sama pada kolom yang sama menunjukkan tidak berbeda nyata }
\end{tabular}

\section{Kecernaan Bahan Kering}

Kecernaan bahan kering hijauan legum pohon ternyata cukup bervariasi. Kecernaan terendah pada kaliandra dan tertinggi pada kelor. Pada umur 1 bulan setelah potong kecernaan bahan kering tertinggi ada pada legume kelor (59.24\%), kemudian turi $(57.27 \%)$, indigofera $(54.04 \%)$ dan lamtoro (43.95\%) sedangkan yang terendah ada pada legum kalindra (24.67\%). Kecernaan bahan kering Kelor dan Turi tidak berbeda nyata tetapi kedua legum ini kecernaan bahan keringnya berbeda nyata dengan indigofera dan lamtoro. Kecernaan bahan kering kaliandra sebagai legum dengan kecernaan terendah berbeda nyata dengan semua legum lainnya.

Umur 2 bulan setelah potong paksa, nilai kecernaan bahan kering semua legum menunjukkan penurunan seiring bertambah tuanya jaringan tanaman. Pada umur panen ini, nilai kecernaan bahan kering tertinggi berada pada legum turi $(57.15 \%)$, dikuti oleh kelor (56.80\%). Nilai kecernaan bahan kering turi dan kelor ini tidak berbeda nyata. Indigofera dan lamtoro memiliki nilai kecernaan yang hampir sama yaitu masingmasing sebesar $44.20 \%$ dan $40.71 \%$. Nilai kecernaan bahan kering terendah pada umur ini adalah tetap ada pada kaliandra $(24.56 \%)$.

Pada umur 3 bulan setelah potong paksa, kelor menunjukkan nilai kecernaan bahan kering yang tertinggi dengan nilai $56,28 \%$, kemudian diikuti oleh turi $(56.02 \%)$, indigofera $(40,21 \%)$ dan lamtoro $33,63 \%$. Dari data terlihat bahwa legume kelor dan turi konsisten memiliki nilai kecernaan bahan kering yang paling tinggi dibanding dengan legum yang lain. Indigofera dan lamtoro menunjukkan nilai kecernaan bahan kering yang konsisten juga pada nilai sekitar $40 \%$ kecernaan bahan kering. Kaliandra terlihat menunjukkan nilai yang paling rendah dalam umur potong yang berbeda-beda.

Tabel 8. Kecernaan Bahan Kering pada berbagai legume yang dipanen dimusim kemarau

\begin{tabular}{lccc}
\hline Spesies legume & \multicolumn{3}{c}{ Kecernaan BK (\%) pada umur potong } \\
\cline { 2 - 4 } & 1 bulan & 2 bulan & 3 bulan \\
\hline Indigofera & $54.04 \pm 1.40 \mathrm{c}$ & $44.20 \pm 1.14 \mathrm{~b}$ & $40.21 \pm 1.17 \mathrm{c}$ \\
Kaliandra & $24.67 \pm 1.60 \mathrm{a}$ & $24.56 \pm 1.16 \mathrm{a}$ & $22.82 \pm 1.15 \mathrm{a}$ \\
Kelor & $59.24 \pm 1.30 \mathrm{~d}$ & $56.80 \pm 1,13 \mathrm{c}$ & $56.28 \pm 1.18 \mathrm{~d}$ \\
Lamtoro & $43.95 \pm 1.50 \mathrm{~b}$ & $40.71 \pm 1.15 \mathrm{~b}$ & $33.63 \pm 1,17 \mathrm{c}$ \\
Turi & $57.27 \pm 1.10 \mathrm{~cd}$ & $57.15 \pm 1,11 \mathrm{c}$ & $56.02 \pm 1.19 \mathrm{a}$ \\
\hline abc huruf yang sama pada kolom yang sama menunjukkan tidak berbeda nyata
\end{tabular}

\section{Kecernaan Bahan Organik}

Kecernaan bahan organik menunjukkan pola yang hampir sama dengan kecernaan bahan kering legum. Nilai kecernaan bahan organik juga menurun seiring pertambahan umur 
tanaman. Pada umur 1 bulan setelah potong paksa kecernaan tertinggi berada pada tanaman kelor dengan nilai kecernaan bahan organik $61.03 \%$ kemudian diikuti oleh turi $(58,75 \%)$, indigofera $(55,27 \%)$, lamtoro (45.83\%) dan yang terendah adalah kaliandra $(24,80 \%)$.

Sebagaimana telah didiskusikan sebelumnya, umur tanaman berpengaruh terhadap kandungan serat kasar hijauan. Kandungan serat kasar dan lignin yang tinggi mengakibatkan selulosa dan hemiselulosa hampir seluruhnya terikat oleh lignin menjadi lignoselulosa dan lignohemiselulosa, sehingga tidak banyak selulosa dan hemiselulosa yang dapat dicerna oleh bakteri rumen dan menyebabkan populasi bakteri rumen rendah. Hal ini sejalan dengan pendapat Wardhana dan Fransisca (2012), yang menyatakan bahwa tingginya kandungan lignin akan mengikat selulosa dan hemiselulosa, membentuk lignoselulosa dan lignohemiselulosa yang sulit dicerna oleh mikroba rumen.

Uji beda nyata pada umur 1 bulan setelah potong paksa terlihat bahwa kcecernaan bahan organic kelor tidak berbeda nyata dengan turi tapi berbeda nyata dengan legum indigofera, lamtoro dan kaliandra. Pada umur 2 bulan setelah potong paksa meski nilai kecernaan menurun seiring dengan meningkatkan umur tanaman, kecernaan bahan organik tertinggi ditunjukkan oleh tanaman turi $(58.61 \%)$ dan oleh kelor $(58,19 \%)$ dan yang terendah adalah tanaman kaliandra (24,70\%). Uji beda nyata pada umur 2 bulan ini, menunjukkan hal yang sama dengan umur 1 bulan, dimana terlihat bahwa kcecernaan bahan organic kelor tidak berbeda nyata dengan Turi tapi berbeda nyata dengan legume indigofera, lamtoro dan kaliandra.

Hal yang sama terjadi pada kecernaan bahan kering pada umur 3 bulan setelah potong paksa, kelor dan turi memiliki nilai kecernaan bahan organik tertinggi dengan masing-masing 56,51\% dan 51,83\%. Sementara nilai kecernaan terendah tetap ditunjukkan oleh tanaman kaliandra $(23,49 \%)$. Pada umur 3 bulan setelah potong paksa uji beda nyata terlihat bahwa kcecernaan bahan organik kelor berbeda nyata dengan turi, indigofera, lamtoro dan kaliandra. Semua tanaman menunjukkan beda nyata dalam nilai kecernaan bahan organiknya.

Tabel 9. Kecernaan Bahan Organik (BO) berbagai legume yang dipanen dimusim kemarau

\begin{tabular}{llcc}
\hline \multirow{2}{*}{ Spesies legume } & \multicolumn{3}{c}{ Kecernaan BO (\%) pada umur potong } \\
\cline { 2 - 4 } \multicolumn{1}{c}{ 1 bulan } & 2 bulan & 3 bulan \\
\hline Indigofera & $55.27 \pm 1.40 \mathrm{c}$ & $44.99 \pm 1.44 \mathrm{~b}$ & $41.01 \pm 1.46 \mathrm{c}$ \\
Kaliandra & $24.80 \pm 1.80 \mathrm{a}$ & $24.70 \pm 1.28 \mathrm{a}$ & $23.49 \pm 1.26 \mathrm{a}$ \\
Kelor & $61.03 \pm 1.60 \mathrm{~d}$ & $58.19 \pm 1.36 \mathrm{c}$ & $56.51 \pm 1.38 \mathrm{e}$ \\
Lamtoro & $45.83 \pm 1.20 \mathrm{~b}$ & $41.29 \pm 1.52 \mathrm{~b}$ & $33.87 \pm 1.55 \mathrm{~b}$ \\
Turi & $58.75 \pm 1.50 \mathrm{~cd}$ & $58.61 \pm 1.15 \mathrm{c}$ & $51.83 \pm 1.15 \mathrm{~d}$ \\
\hline
\end{tabular}

${ }^{\text {abc }}$ huruf yang sama pada kolom yang sama menunjukkan tidak berbeda nyata

\section{KESIMPULAN}

Pertumbuhan kembali yang paling tinggi dan juga menghasilkan hijauan paling banyak yaitu hijauan legum kaliandra namun memiliki nilai kecernaan paling rendah. Tanaman legum lainnya yang mendekati produksi kaliandra adalah turi dan indigofera. Kandungan bahan kering dan bahan organik tanaman legum yang dipanen pada musim kemarau sangat tinggi dengan kandungan serat kasar rendah. Kandungan protein legum yang dipanen pada musim kemarau menunjukkan nilai kandungan protein yang relatif rendah, akan tetapi nilai protein ini tetap masih diatas nilai kandungan protein kasar rumput. Semua hijauan legum yang 
diuji menunjukkan palatabilitas yang baik. Dengan demikian, semua hijauan legum tersebut potensial untuk dikembangkan sebagai sumber hijauan pakan bagi ternak ruminansia dimusim kemarau.

\section{DAFTAR PUSTAKA}

Ambisi, G.N., T. Dhalika dan Mansyur. 2014. Pengaruh penggunaan indigofera falcata sebagai pengganti konsentrat dalam ransum sapi perah berbasis jerami padi terhadap produksi asam lemak terbang dan NH3. Pastura. 4 (1) : 11-15.

AOAC. 2005. Official Method of Analysis of the Association of Official Analitycal Chemist. 18 Th edn. Published by the Association of Official Analytical Chemists, Washington.

Bamualim AM. 2009. The dynamic of native grass resources in dry-land area of Indonesia to support beef cattle production: case study of Nusa Tenggara. In: Proceeding of International Seminar on Forage Based Feed Resources. Bandung, 37 Agustus 2009. Taipei (Taiwan): Food and Fertilizer Technology Centre (FFTC) ASPAC, Livestock Research Centre-COA, ROC and IRIAP. p. 142-148.

Barnes, R. F., C. J. Nelson., K. J. Moore and M. Collins. 2007. Forages. The Science of Grassland Agriculture.Volume II. 6th edn. Blackwell Publishing, USA.

Djuned, H., Mansyur, dan Wijayanti, H.B. 2005. Pengaruh umur pemotongan terhadap kandungan fraksi serat hijauan murbei (Morus indica L. Var. Kanva-2). Seminar Nasional Teknologi Peternakan dan Veteriner.
Gardner, F. P., R. B. Pearce and R. L. Mitchell. 2008. Physiology of Crop Plants (Fisiologi Tanaman Budidaya. Alih bahasa H. Susilo). UI Press, Jakarta.

Hutabarat, J., Erwanto, Wijaya AK. 2018. Penngaruh umur pemotongan terhadap kadar protein kasar dan serat kasar Indigofera zollingeriana. Jurnal Riset dan Inovasi dan Inovasi Peternakan. 1: $21-24$.

Koten, B. B., R. D. Soetrisno, N. Ngadiyono, dan B. Suwignyo. 2012. Forage productivity of arbila (Phaseolus lunatus) at various levels of rhizobium inoculants and harvesting times. J. Indonesian Trop. Anim. Agric. 37: 286293.

Koten B.B. Redempta Wea, Agustinus Semang, Bambang Hadisutanto, Maria Klara Salli. 2017. Regrowth ability of arbila (phaseolus lunatus 1.) after grassed at different dosage of rhizobium inoculant and age of plant when start grazed at dry land. Bulletin of Animal Science, 41: 439 $-447$.

Mannetje, L.t dan R.M. Jones, 2000. Sumber Daya Nabati Asia Tenggara. Pakan. PT Balai Pustaka (Persero) Jakarata bekerjasama dengan PROSEA Indonesia Bogor.

Mansyur, Djuned, H., Dhalika, T., Hardjosoewignyo, S., and Abdullah, L. 2005. Pengaruh interval pemotongan dan inveksi gulma Chromolaena odorata terhadap produksi dan kualitas rumput Brachiaria humidicola. Media Peternakan.

Peoples, M.B. and E.T. Craswell. 1992. Biological Nitrogen Fixation: Investments, Expectations and Actual Contributions to Agriculture. Plant and Soil. 141: 13-39. 
Purbajanti, E. D. 2013. Rumput dan Legum Sebagai Hijauan Makanan Ternak. Graha Ilmu, Semarang.

Reksohadiprodjo, S. 1994. Produksi Tanaman Hijauan Makanan Ternak Tropik. Edisi Ketiga. BPFE. Gajah Mada, Yogyakarta.

Salisbury, F.B. dan C.W. Ross. 1995. Fisiologi Tumbuhan. Naskah Terjemahan. Penerbit ITB, Bandung.

Setiyaningrum, E., I Nyoman Kaca, Ni Ketut Etty Suwitari. 2017. Pengaruh Umur Pemotongan Terhadap Produksi dan Kualitas Nutrisi Tanaman Indigofera (Indigofera Sp). Gema Agro. 23: $59-62$.

Steel, R.G.E.D. dan J. H. Torrie. 1991. Prinsipdan Prosedur Statistika; Suatu Pendekatan Biometrik. Edisi ke 2. P.T. Gramedia Pustaka Utama. Jakarta.
Sumiahadi, A., M. A. Chozin, dan D. Guntoro. 2016. Evaluasi pertumbuhan dan perkembangan Arachis pintoi sebagai biomulsa pada budidaya tanaman di lahan kering tropis. J. Agron. Indonesia 44: 98-103.

Tillman, A.D., H. Hartadi, S. Reksohadiprojo, S. Prawirokusumo. dan S. Lebdosoekojo. 1998. Ilmu Makanan Ternak Dasar. Edisi Keenam. Gadjah Mada University Press. Yogyakarta.

Tilley JMA, Terry RA. 1963. A two-stage technique for the in vitro digestion of forage crop. J Br Grassl Soc. 18:104-11.

Wardhana S. dan Fransisca M. S. 2012. Fermentasi Jerami Padi Menggunakan White rot fungi dan Suplementasi Saccaromyces cerevisiae Pengaruhnya terhadap Kecernaan Nutrien Secara In Vitro. Jurnal Agripet : 12: 1- 6. 